\title{
Sistem Informasi Pembayaran Angsuran Debitur pada PT. Pas Jaya
}

\author{
Ahmad Fitri Boy $^{1}$, Dr. Asyahri Hadi Nasyuha ${ }^{2}$, Jufri Halim ${ }^{3}$, Trinanda Syahputra ${ }^{4}$, Egi Affandi ${ }^{5}$ \\ ${ }^{12345}$ Sistem Informasi, STMIK Triguna Dharma \\ Email: ${ }^{1}$ ahmadfitriboy@gmail.com, ${ }^{2}$ asyahrihadinasyuha@gmail.com, ${ }^{3}$ jufrihalim@gmail.com, \\ ${ }^{4}$ trinandasyahputra@gmail.com, ${ }^{5}$ egiaffandi@gmail.com.
}

\begin{abstract}
Abstrak
PT. Pas Jaya Medan sebuah perusahaan yang membutuhkan sebuah sistem informasi berbasis komputer dalam melakukan suatu pekerjaan. Perusahaan ini sudah menggunakan software komputer terutama ms. excel untuk menginput data angsuran debitur, namun penggunaannya belum maksimal dan sistem ini masih banyak kelemahannya yaitu, dalam mencari data angsuran debitur dan laporan pembayaran angsuran debitur membutuhkan waktu yang lama. Dengan adanya sistem informasi yang tepat dan akurat tersebut sehingga dapat meringankan dan mempermudah karyawan PT. Pas Jaya dalam mengolah segala data yang terkait dalam pembayaran kredit debitur dan menghasilkan sebuah laporan yang lebih detail.
\end{abstract}

Kata kunci: Sistem Informasi, Pengelolaan Laporan, Data Debitur, Data Angsuran

\begin{abstract}
PT. Pas Jaya Medan is a company that requires a computer-based information system to do a job. This company is already using computer software, especially Ms. excel to input debtor installment data, but its use has not been maximized and this system still has many weaknesses, namely, finding debtor installment data and debtor installment payment reports takes a long time. With the right and accurate information system so that it can ease and facilitate the employees of PT. Pas Jaya in processing all data related to debtor credit payments and producing a more detailed report.
\end{abstract}

Keywords: Information System, Report Management, Debtor Data, Installment Data

\section{PENDAHULUAN}

Perkembangan teknologi saat ini semakin pesat, semua perusahaan sangat membutuhkan suatu informasi,berupa alat bantu komputer yang dapat membantu dalam menyelesaikan semua pekerjaan. terbukti dengan dapat terselesaikannya persoalan-persoalan dalam suatu instansi perusahaan dengan baik dan lebih mudah. Komputer juga membutuhkan sumber daya manusia yang berkompetensi, untuk itu tidak dapat dipungkiri bahwa teknologi komputer harus sejalan dengan kemampuan sumber daya manusia dalam menggunakan teknologi tersebut sebagai alat bantu serta menambah wawasan dunia kerja. Banyak yang percaya bahwa teknologi informasi akan menjadi pendorong utama kekayaan ekonomi di Industri. Namun, penerapan teknologi informasi untuk mendukung proses bisnis perusahaan membawa risiko keamanan informasi yang besar. Diperlukan tata kelola keamanan informasi yang komprehensif yang dapat memenuhi standar dan peraturan keamanan informasi (Syahbuddin, Afrida, Azzahro, \& Phusavat, 2020). Dengan Rancangan UML dipergunakan untuk mendokumentasikan \& menspesifikasikan sehingga bidang tersebut menjadi lebih terstruktur. (Affandi, 2018)

PT. Pas Jaya Medan sebuah perusahaan yang membutuhkan sebuah sistem informasi berbasis komputer dalam melakukan suatu pekerjaan. Dan Untuk menjamin keterpaduan, ketersediaan, dan validitas data indikator kinerja, diperlukan pengelolaan informasi yang baik dengan sistem informasi yang dimanfaatkan oleh seluruh unit kerja. (Putri, 2021). Perusahaan ini sudah menggunakan software komputer terutama ms. excel untuk menginput data angsuran debitur, namun penggunaannya belum maksimal dan sistem ini masih banyak kelemahannya yaitu, dalam mencari data angsuran debitur dan laporan pembayaran angsuran debitur membutuhkan waktu yang lama.

Dengan adanya sistem informasi yang tepat dan akurat tersebut sehingga dapat meringankan dan mempermudah karyawan PT. Pas Jaya dalam mengolah segala data yang terkait dalam pembayaran kredit debitur dan menghasilkan sebuah laporan yang lebih detail.

Dari latar permasalahan tersebut diangkat sebuah Judul Pengabdian Kepada Masyarakat (PKM) dengan Judul "Sistem Informasi Pembayaran Angsuran Debitur pada PT. Pas Jaya". 


\section{METODE PELAKSANAAN}

Persiapan kegiatan dilaksanakan selama 3 minggu. Berikut ini peta persiapan yang akan dilaksanakan pada PT. PAS Jaya selama 3 minggu dan dibagi menjadi beberapa peta kegiatan.

Persiapan program dilakukan pada bulan Januari 2021 dengan susunan pelaksana terdiri dari ketua dan anggota sebagai berikut :

1. Ahmad Fitri Boy, S.Kom, M.Kom (Ketua Tim)

2. Jufri Halim, SE. MM (Anggota Tim)

3. Egi Affandi, S.Kom, M.Kom (Anggota Tim)

4. Trinanda Syahputra, S.Kom, M.Kom (Anggota Tim)

5. Dr. Asyahri Hadi Nasyuha, S.Kom, M.Kom (Anggota Tim)

Susunan anggota di atas meliput dosen STMIK Triguna Dharma Program Studi Sistem Informasi, dan Teknik Komputer. Ketua pengusul dan anggota bekerja sama dalam kegiatan yang meliputi perencanaan, pelaksanaan, pengawasan, pengevaluasian kegiatan dari awal hingga akhir kegiatan.

Penyelenggaraan kegiatan ini akan dilaksanakan selama 3 minggu, Bulan April 2021.

Tabel 2 Peta Kegiatan Secara Umum

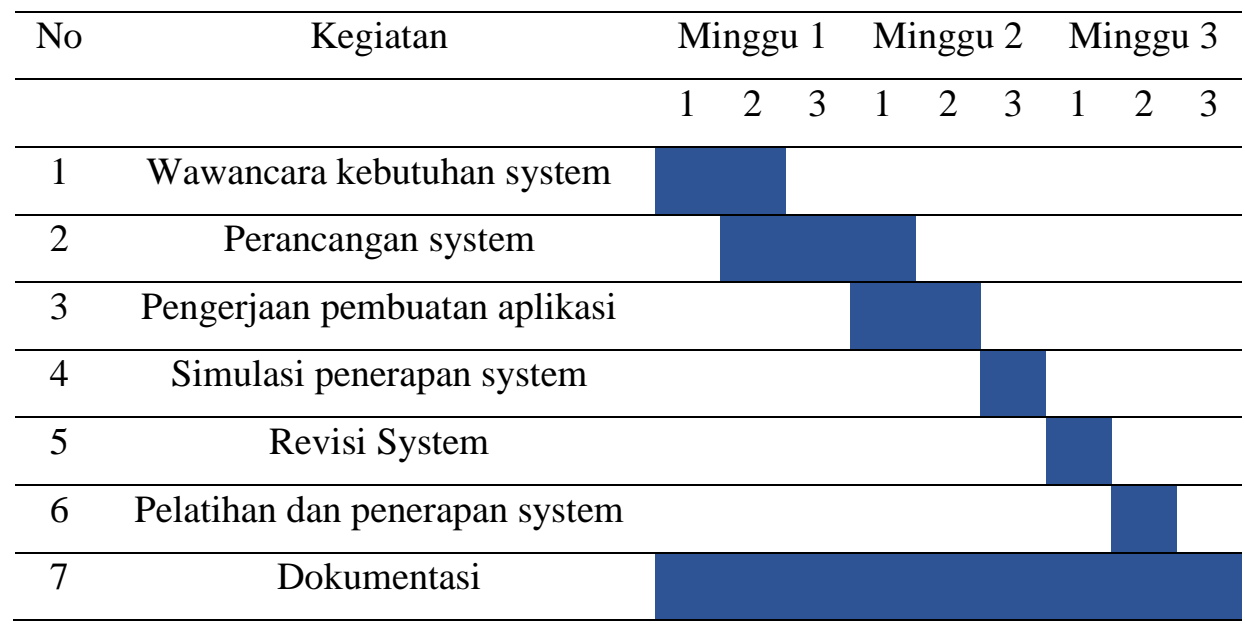

Pelaporan hasil kegiatan ini direncanakan akan selesai pada akhir bulan April 2021. Dengan rincian melaporkan seluruh pertanggung jawaban pada semua pihak yang berkepentingan dari kegiatan ini.

\section{HASIL DAN PEMBAHASAN}

Sesuai dengan bentuk pendekatan penelitian kualitatif dan sumber data yang akan digunakan, maka instrumen pelaksanaan dalam melaksanakan kegiatan pengabdian ini adalah menggunakan teknik pengumpulan data yang dengan analisis dokumen, observasi dan wawancara. Untuk mengumpulkan data dalam kegiatan ini diperlukan cara-cara atau teknik pengumpulan data tertentu, sehingga proses penelitian dapat berjalan lancar. Instrumen pelaksanaan digunakan untuk mengumpulkan data dalam pendekatan kualitatif pada umumnya menggunakan teknik observasi, wawancara, dan studi dokumenter, atas dasar konsep tersebut, maka ketiga teknik pengumpulan data diatas digunakan dalam penelitian ini.

\subsection{Hasil Perancangan Modul}

Pada tahap ini, terdapat komponen sistem menjadi modul-modul yang lebih kecil dan ditentukan matriks CRUD untuk setiap modul. Hal ini dilakukan guna mempermudah dalam coding aplikasi. Rincian mengenai perancangan modul terdapat pada tabel Berikut ini: 
Tabel 3 Tabel Matrik CRUD

\begin{tabular}{|c|c|c|c|c|c|c|c|}
\hline \multirow[b]{2}{*}{ No } & \multirow[b]{2}{*}{ Komponen } & \multirow[b]{2}{*}{ Modul } & \multicolumn{5}{|c|}{ Pengguna } \\
\hline & & & Admin & Kasir & $\begin{array}{c}\text { Staff } \\
\text { Penjualan }\end{array}$ & Analis & $\begin{array}{l}\text { Pimpin } \\
\text { an }\end{array}$ \\
\hline 1. & Admin & - & CRUD & $\mathrm{R}$ & $\mathrm{X}$ & $\mathrm{X}$ & $\mathrm{R}$ \\
\hline 2. & Penjualan & - & $\mathrm{X}$ & CRUD & $\mathrm{X}$ & $X$ & $\mathrm{R}$ \\
\hline 3. & Sales & - & CRUD & $\mathrm{R}$ & $\mathrm{X}$ & $\mathrm{X}$ & $\mathrm{R}$ \\
\hline 4. & Inventory & - & CRUD & $\mathrm{R}$ & $\mathrm{X}$ & $\mathrm{X}$ & $\mathrm{R}$ \\
\hline \multirow[t]{2}{*}{5.} & Transaksi & Kredit & CRUD & $\mathrm{R}$ & $\mathrm{X}$ & $X$ & $\mathrm{R}$ \\
\hline & & $\begin{array}{l}\text { Pembayara } \\
\mathrm{n}\end{array}$ & CRUD & $\mathrm{R}$ & $\mathrm{X}$ & $\mathrm{X}$ & $\mathrm{R}$ \\
\hline 6. & debitur & - & CRUD & $\mathrm{R}$ & $\mathrm{X}$ & $\mathrm{X}$ & $\mathrm{R}$ \\
\hline 8. & kreditur & - & $\mathrm{X}$ & CRUD & $X$ & $\mathrm{X}$ & $\mathrm{R}$ \\
\hline 10. & Absensi & - & $\mathrm{X}$ & $\mathrm{X}$ & $\mathrm{X}$ & CRUD & $\mathrm{R}$ \\
\hline \multicolumn{2}{|c|}{ KETERANGAN } & \multicolumn{6}{|c|}{$\mathrm{C}=$ Creat, $\mathrm{R}=$ Read, $\mathrm{U}=$ Update, $\mathrm{D}=$ Delete, $\mathrm{X}=$ No Access } \\
\hline
\end{tabular}

\subsection{Hasil Modul Sistem}

a. Dashboard System

Dashboard system digunakan untuk mengconfigurasikan seluruh menu-menu yang ada di dalam system. Berikut tampilan dashboard system :

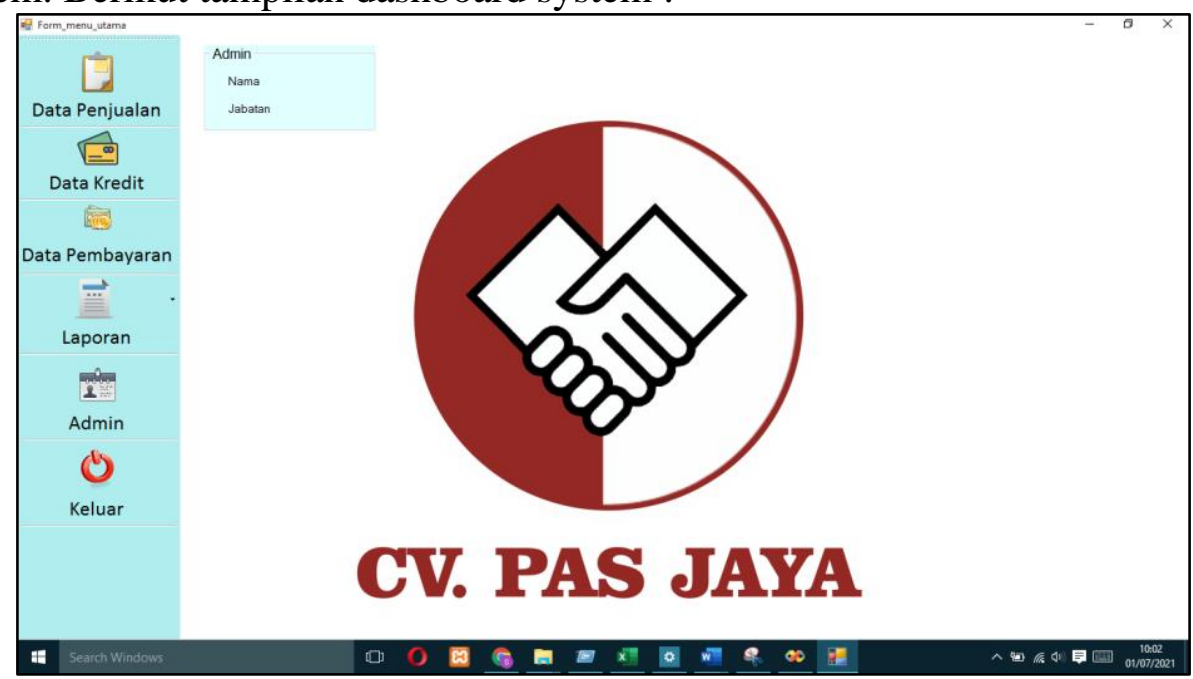

Gambar 1. Tampilan Dashboard System

b. Menu Data Penjualan

Menu data openjualan berfungsi untuk melakukan proses penjualan produk secara kredit, berikut tampilan menu data penjualan: 


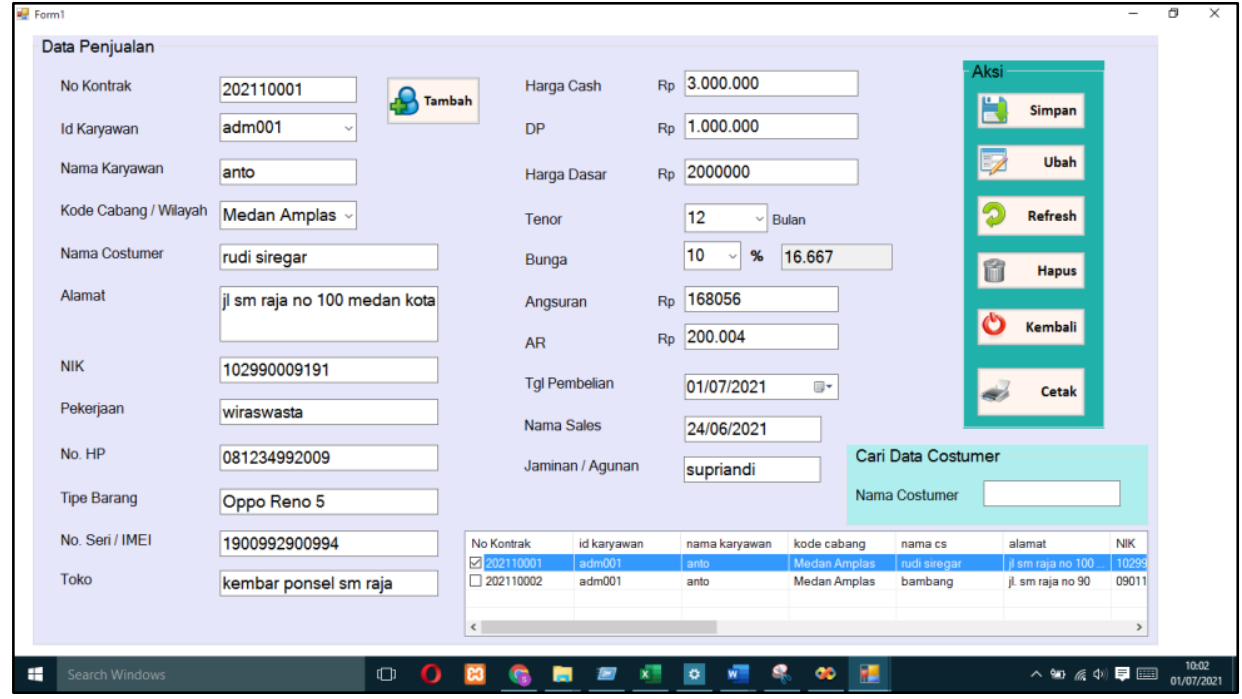

Gambar 2. Tampilah Menu Data Penjualan

c. Menu Data Kredit

Menu data kredit berfungsi untuk mencetak data riwayat pembayaran kredit nasabah, berikut tampilan menu data kredit:

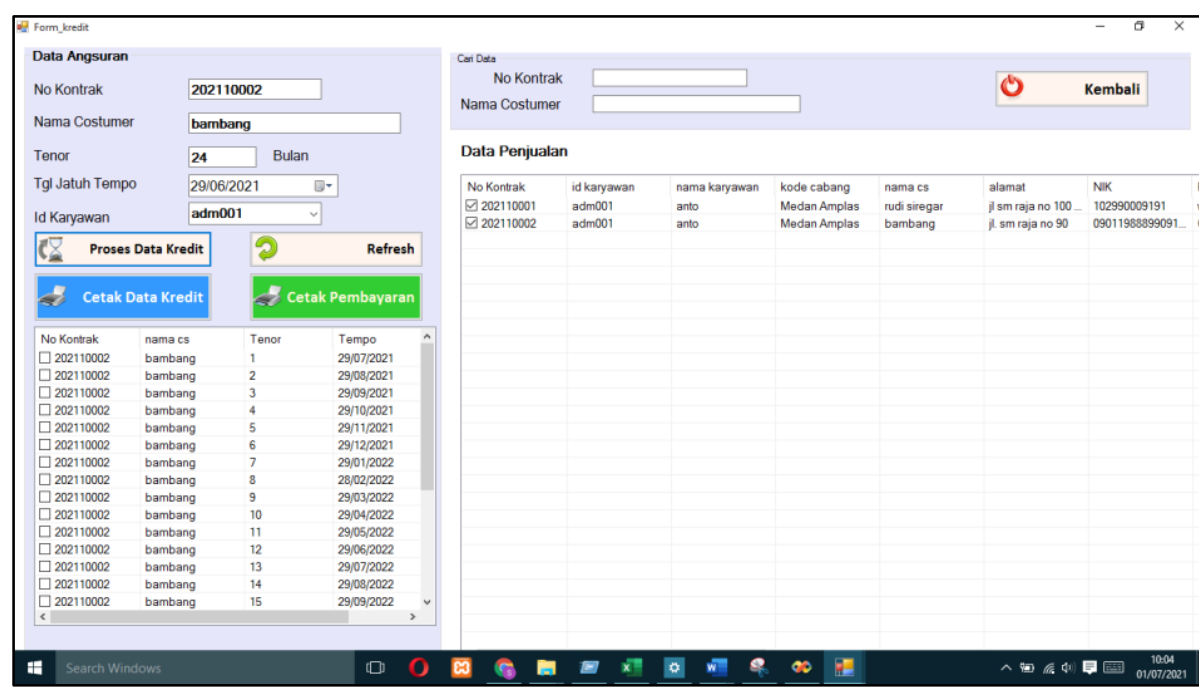

Gambar 3. Tampilan Menu data kredit

d. Menu Data Pembayaran

Pada Menu digunakan untuk merekap pembayaran nasabah. Berikut gambar menu data pembayaran : 


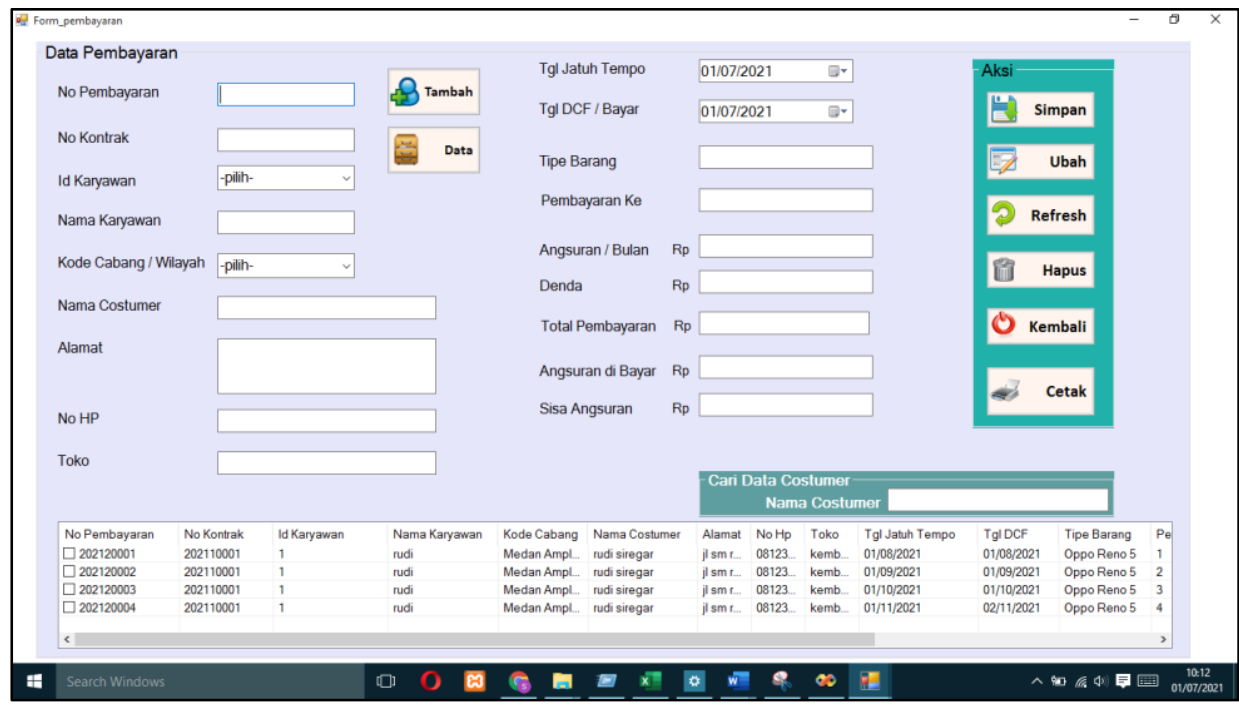

Gambar 4. Tampilan menu data pembayaran

e. Report Kuitansi Penjualan

Pada report ini berfungsi untuk mencetak laporan data pembayaran nasabah, berikut tampilan kuitansi penjualan :

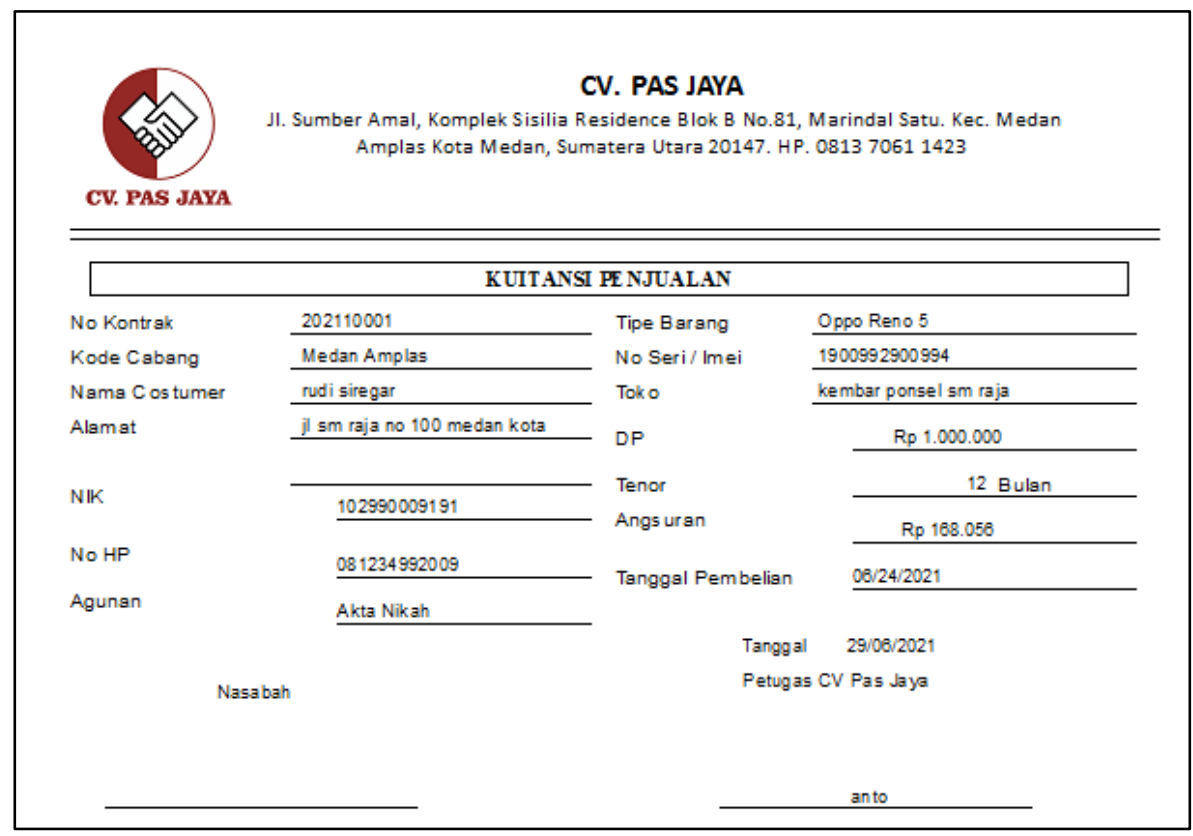

Gambar 5. Tampilan Kuitansi Penjualan

f. Report Kuitansi Pembayaran

Pada report ini berfungsi untuk mencetak laporan data pembayaran nasabah, berikut tampilan kuitansi penjualan : 


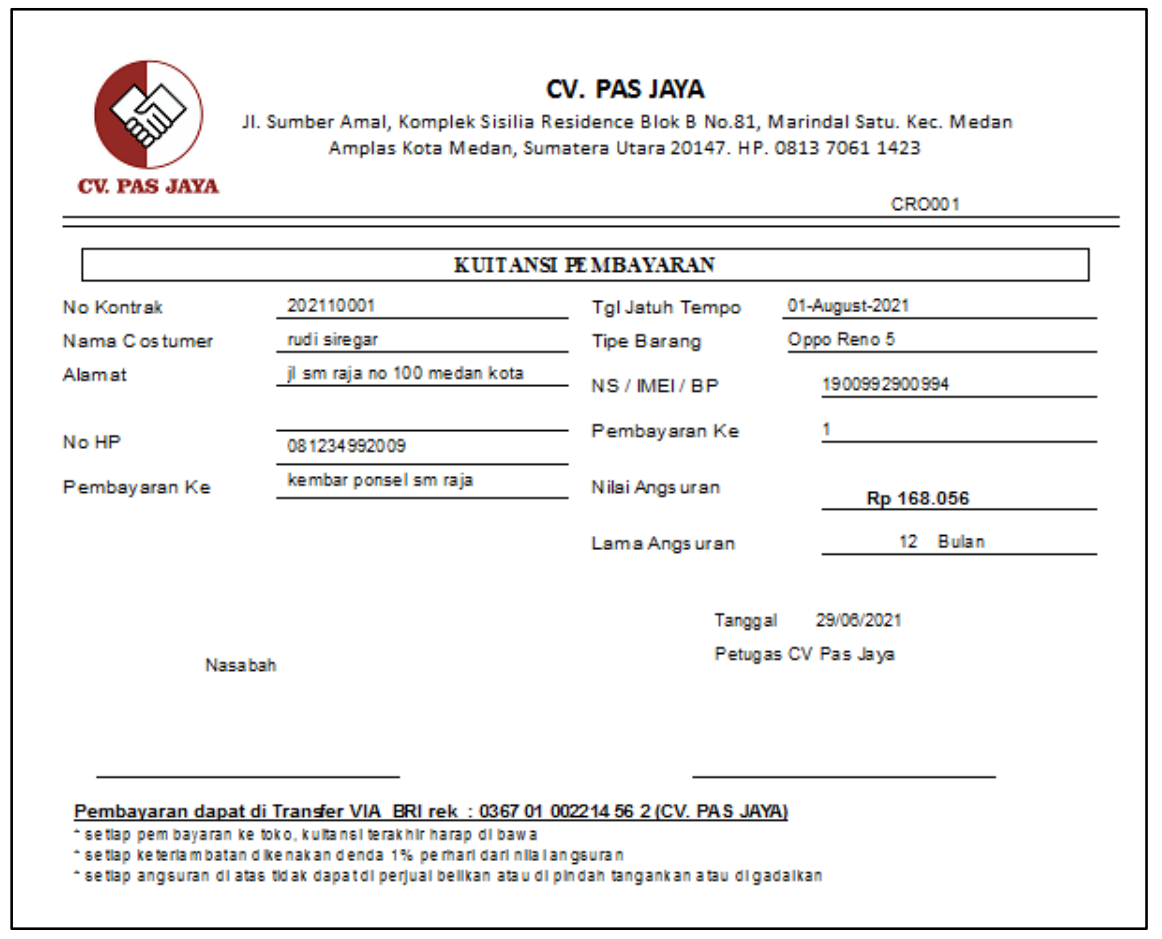

Gambar 6. Tampilan Report kuitansi Pembayaran

\section{g. Menu Report Jatuh Tempo}

Pada report ini berfungsi untuk mencetak laporan data jatuh tempo nasabah, berikut tampilan kuitansi jatuh tempo :

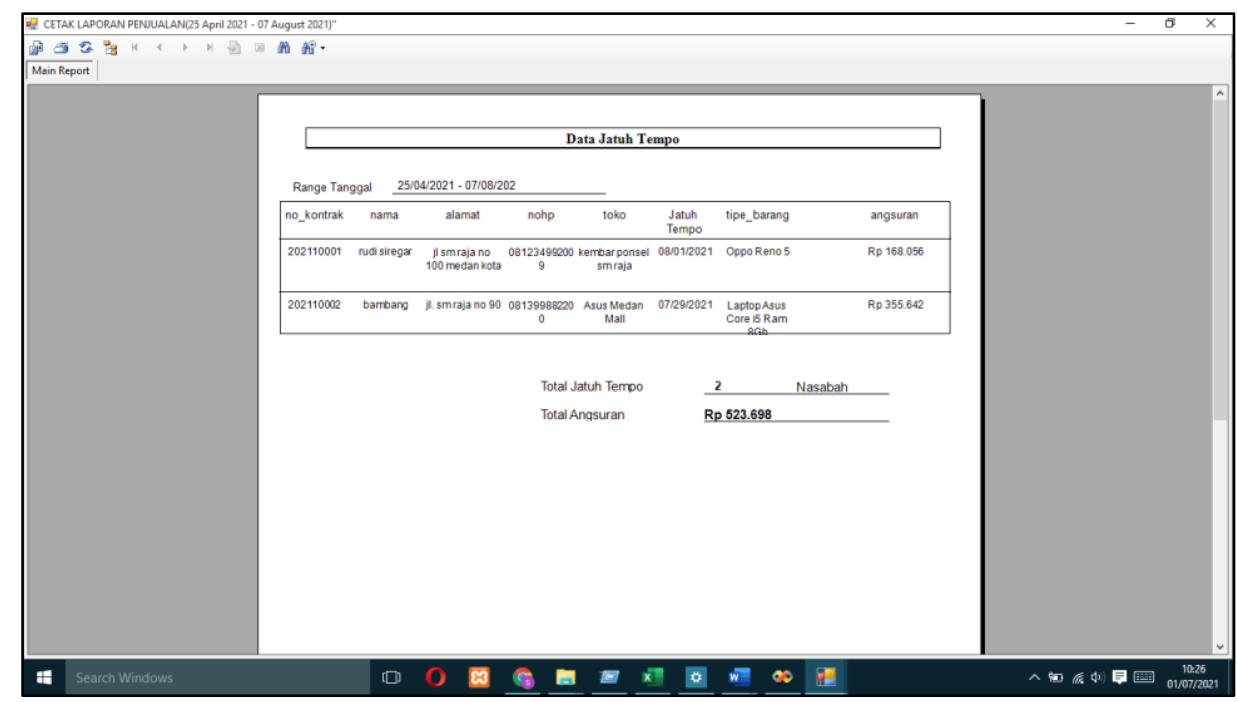

Gambar 7. Tampilan Report Jatuh Tempo

\section{KESIMPULAN}

Dari hasil perancangan Sistem Informasi Pembayaran Angsuran Debitur Pada PT. PAS Jaya Medan yang telah diselesaikan ini dapat diambil kesimpulan diantaranya adalah Sistem Informasi dirancang dengan berbasis dekstop yang dapat mempermudah melakukan penginputan data yang dibutuhkan oleh PT. PAS Jaya Medan. Dan Laporan dihasilkan dengan cara menggunakan sistem pengolahan data pembayaran angsuran debitur yang dapat lebih mudah dilakukan untuk menghasilkan laporan sesuai kebutuhan, dibandingkan dengan sistem manual. 


\section{SARAN}

Dari hasil perancangan Sistem Informasi Pembayaran Angsuran Debitur Pada PT. PAS Jaya Medan yang telah diselesaikan ini dapat diambil kesimpulan bahwa Sistem Informasi dirancang dengan cara menggunakan Visual Studio 2008 yang dapat mempermudah melakukan penginputan data yang dibutuhkan oleh PT. PAS Jaya Medan. Dan Laporan dihasilkan dengan cara menggunakan sistem pengolahan data pembayaran angsuran debitur yang dapat lebih mudah dilakukan untuk menghasilkan laporan sesuai kebutuhan, dibandingkan dengan sistem manual.

\section{DAFTAR PUSTAKA}

Affandi, E. (2018). Pemodelan Uml Manajeman Sistem Inventory. Jurnal Teknologi Sistem Informasi dan Sistem Komputer TGD, Vol.1, No.2, Juli 2018, pp.14-25(Vol.1, No.2, Juli 2018, pp.1425), pp.14-25.

Putri, T. S. (2021). Information Management and Information System Analysis to Support the Achievement of University Performance Agreements with the Government. Jurnal Sistem Informasi, 30-43.

Syahbuddin, B. H., Afrida, W. Y., Azzahro, F., \& Phusavat, K. (2020). The Implementation of Multiple Information Security Governance (ISG) Frameworks Strategy and Critical Success Factors in Indonesia's Oil and Gas Industry: Case Study of PT X. Jurnal Sistem Informasi, 4356. 